\title{
Yabancı Dil Olarak Türkçe Öğretimi Ders Kitaplanı Üzerine Yapılan Araştırmaların Eğilimleri
}

\author{
Ömer Kemiksiz*
}

Makale Geliş Tarihi: 27/11/2020 Makale Kabul Tarihi: 01/02/2021

DOI: $10.35675 /$ befdergi. 832492

$\ddot{O} z$

Bu çalışmanin amacı yabancı dil olarak Türkçe öğretimi ders kitapları üzerine yapllan araştırmaları çeşitli açılardan incelemektir. Nitel araştırma deseninde doküman incelemesiyle gerçekleştirilen araştırmada 2010-2020 yılları arasında yayımlanmış 100 makale ve 142 lisansüstü tez olmak üzere 242 çalışma incelemeye alınmıştır. Araştırma bulgularına göre en fazla çalışmanın 2019 ve 2018 yıllarında yapıldı̆g belirlenmiştir. Tezlerin öğrenim kademelerine bakıldığında yüksek lisans tezlerinin çoğunlukta olduğu, İstanbul Üniversitesinin konuyla ilgili en fazla tezin hazırlandı̆̆ kurum olduğu ve tezlerin daha çok "Prof. Dr." ile "Doç. Dr." unvanına sahip danışmanlar tarafından yürütüldüğü tespit edilmiştir. Makale yayınlarında tek veya çift yazarlı çalışmaların ön plana çıktığl görülürken temel düzeydeki ögrenciler için hazırlanan kitapların araştırmalarda daha fazla incelendiği belirlenmiştir.

Anahtar Kelimeler: Araştırma ĕgilimleri, ders kitapları, Türkçe öğretimi, yabancı dil olarak Türkçe öğretimi

\section{Trends of Studies on Teaching Turkish as a Foreign Language Textbooks}

\begin{abstract}
The aim of this study is to analyze the studies on textbooks on teaching Turkish as a foreign language from various aspects. Carried out in the qualitative research design by analyzing documents, 242 studies including 100 articles and 142 postgraduate theses published between 2010 and 2020 were analyzed. According to the research findings, it was determined that the highest number of studies was conducted in 2019 and 2018. Considering the education levels of these theses, it has been determined that master's theses are the majority, that Istanbul University is the institution where most theses were prepared on the subject, and that theses were mostly written by advisors holding the title "Prof. Dr." and "Assoc. Dr.". While it has been observed that single or double author studies are prominent in article publications, it has been determined that the books prepared for basic students were analyzed more in these studies.
\end{abstract}

Keywords: Research trends, teaching Turkish, teaching Turkish as a foreign language, textbooks

\footnotetext{
* Bartın Üniversitesi Eğitim Fakültesi, Bartın, Türkiye, okemiksiz@bartin.edu.tr, ORCID: 0000-0001$8628-6203$ (D)
}

Kaynak Gösterme: Kemiksiz, Ö. (2021). Yabancı dil olarak Türkçe öğretimi ders kitapları üzerine yapılan araştırmaların eğilimleri. Bayburt Eğitim Fakültesi Dergisi, 16(Özel Sayı), 34-56. https://doi.org/10.35675/befdergi.832492 


\section{Giriş}

Günümüzde çeşitli alanlarda yaşanan gelişmelerin eğitim sistemlerini etkilemesi kaçınılmazdır. Bir ülkenin eğitim alanında başarıya ulaşabilmesinde ülke eğitim sisteminin çağın gereklerine uygun şekilde düzenlenmesi son derece önem arz etmektedir. Bu sebeple belirli aralıklarla eğitim programlarının gözden geçirilmesi, programlardaki eksiklik ve aksaklıkların giderilmeye çalışılması bir tercihten öte bir ihtiyaç hâlini almıştır. Bunun yanında programların geliştirilmesi ve güncellemesi kadar o programların uygulanmasında görev alacak personel ve kullanılacak yardımcı materyallerin de eğitimin kalitesinin artmasında önemli bir yeri vardır.

Ders programlarının hedef kitlelere ulaştırılabilmesi ve istendik sonuçlar oluşturabilmesi için taşıyıcı ögelere gerek duyulduğunu belirten Yalınkılıç’a (2014: 5) göre "çok geniş kitlelerin farklı düzeylerdeki bilişsel, duyuşsal ve devinişsel gelişimlerinin sağlanabilmesi açısından gerekli olan bilgi, beceri ve davranış biçimlerinin bu kitlelere ulaştırılabilmesinde yazılı/nesnel iletişim birimlerine ihtiyaç duyulur." $\mathrm{Bu}$ iletişim birimlerinden biri de teknoloji alanında yaşanan hızlı gelişmelere rağmen değerinden bir şey kaybetmeyen, ders materyali denilince akla ilk gelen ürünlerden olan ders kitaplarıdır.

"Bir eğitim programında yer alan hedef, içerik, öğretme-öğrenme süreci ile ölçme değerlendirme boyutlarına uygun olarak hazırlanmış ve öğrenme amaçlı kullanılan basılı öğretim materyali" (Demirel \& Kıroğlu, 2020: 2), "belli bir dersin öğretimi için ve belli bir düzeydeki öğrencilere yönelik olarak yazılan, içeriği öğretim programına uygun olan, incelemesi yapılmış ve onaylanmış temel kaynak" (Gülersoy, 2013: 8), "öğrencinin gelişim özelliklerine ve düzeyine uygun olarak hazırlanmış metinlerden oluşan, öğretim programlarının ilkeleri doğrultusunda hazırlanan ve içerdiği bilgileri öğrenciye sunan öğrenme-öğretme materyali” (Şahin, 2012: 130) şeklinde tanımlanan ders kitapları, öğretmen ve öğrencilerin öğrenme sürecindeki faaliyetlerinin bir düzen içerisinde yürütülmesini sağlayan önemli araçlardandır (Göçer, 2008). Bu nedenle bir ders için belirlenen amaçlara ulaşmada bu araçların etkili bir şekilde kullanılması gereklidir.

Kuşakların içinde yaşadıkları topluma ait kültürü ve evrensel değerleri kazanmalarına, ortak değerler etrafinda birleşmelerine yardımcı olan (Coşkun \& Taş, 2008), böylece toplum içerisinde ortak kültürün oluşmasına, geçmişle bugün, bugünle yarın arasındaki köprünün kurulmasına ve ortak bir anlayış geliştirilmesine katkı sağlayan (Özkan, 2010) ders kitapları, “öğrencinin derse hazırlanması, okulda formal olarak işlenen bir konuyu kendi algılama hızına uygun şekilde çalışarak kavraması, içerdiği ödev ve alıştırmalar açısından da çok önemlidir" (Aydın, 2010: 208). Ders kitaplarının öğrencilere, bireysel öğrenme imkânı sunduğunu dile getiren Güzel ve Şimşek’e (2012: 179) göre “öğrenci derse hazırlık sürecinde, işlenmiş konunun tekrar edilmesi sürecinde, derste anlaşılmayan yerlerin bireysel olarak anlaşılmasında, işlenen konuların pekiştirilmesinde ders kitaplarından faydalanmaktadır." $\mathrm{Bu}$ materyaller aracılığıyla öğrencilerin, öğretmenlerinin anlattıklarını istedikleri zaman, istedikleri tempoda ve istedikleri kadar tekrar etme imkânına kavuştuğunu söyleyen Küçükahmet'e (2004) göre özellikle sözel öğretimin oluşturduğu boşluğu doldurma görevi kitapları değerli 
kılmaktadır. "Öte yandan ders kitaplarının diğer eğitim araç-gereçlerine göre daha ekonomik olmaları, öğrenmeyi bireyselleştirmeleri, öğretimi yapısallaştırmaları, diğer pek çok öğretim aracıyla birlikte ve aynı anda kullanılabilmeleri, pek çok bilgiyi belli bir düzen içerisinde sunmaları vb. avantajları da eğitim öğretim etkinliklerinde yoğun olarak tercih edilmelerini sağlamaktadır" (Şahin, 2008: 134). Yalınkılıç'a (2014: 5) göre de ders kitapları "eğitimin kitlesel boyutu düşünüldüğünde bireysel ve toplumsal yaşamı çevreleyen tüm bilgi, beceri ve değerlerin tek tek bireylere taşınabilmesinin en kolay ve en ekonomik yolunu oluşturmaktadır." $\mathrm{Bu}$ durumda ders kitapları eğitim tartışmalarında sürekli gündemde olan "fırsat eşitliği”" konusunda da önemli bir noktadadır. Bu eşitliğin sağlanması ise öğrenciler kadar dersleri yürüten öğretmenler için de bir avantaj oluşturmakta, bu sebeple kitaplar öğretmenlerin de temel başvuru materyallerinden biri olmaktadır.

Ders kitapları "öğretmen ve yöneticilerin amaç ve hedeflerini gerçekleştirmesinde bir sistem oluşturmasının yanı sıra derslerin yürütülmesinde bir rehber, sürecin ve öğrenci başarısının fiziksel değerlendirilmesinde bir araç olarak hizmet eder" (Tüm \& Ceyhan Bingöl, 2017: 432). Bundan dolayı "eğitim sisteminde yapılan yeniliklerin başarıya ulaşması için öğretmenlerin ders kitaplarındaki değişikliklerin takipçisi olması, işleyişe hâkim olması ve ders kitaplarının öğretmenden ve öğrenciden ne istediğini özümsemesi gerekir" (Öztürk \& Çerçi, 2019: 879). Öğretimde öğretmenin temel yardımcısı olan kitaplar, öğretmenin gücünü daha iyi kullanmasına ve dersini daha sistematik anlatmasına imkân verir (Küçükahmet, 2004). Richards'a (2001) göre ders kitapları öğretmene, ders için öğretim materyali hazırlaması gereken zamandan tasarruf etmesini sağladığı gibi öğretim deneyimi yetersiz olan öğretmenin kendini yetiştirmesi noktasında da bir eğitim aracı olur. Ders kitaplarının birçok yerde müfredat görevi üstlendiğini düşünen Ur (1999) da deneyimsiz veya zaman zaman bilgilerinden emin olamayan öğretmenler için bu kitapların bir rehber görevi gördüğünü belirtmektedir. Böylesine önemli görevleri olan ders kitaplarının, bu görevleri uygun şekilde yerine getirebilmesinin yolu ise nitelikli bir şekilde hazırlanmalarından geçmektedir.

Eğitimde yapılan yeniliklerin en somut hâli, ders kitaplarında görüldüğünden bu kitapların eğitimdeki yeniliklerin gerçekleşmesine katkı sağlama gibi bir işlevi vardır (Öztürk \& Çerçi, 2019). Bu işlevinden dolayı hazırlanacak olan ders kitaplarının nitelikli olması eğitim-öğretim sürecinin en önemli gereklerinden biridir (Tanrıkulu \& Akgül, 2019). Öğrenme-öğretme sürecinde önemli bir yer tutan ders kitaplarından gerektiği gibi istifade edebilmek için hazırlanma aşamasında bazı özelliklerin dikkate alınması gerektiğini vurgulayan Mentiş Taş’a (2007) göre ders kitapları öncelikle öğretim programına parelel olarak hazırlanmalı, bununla birlikte görsel düzen, tasarım, fiziksel yapı, içerik, dil ve anlatım gibi özellikler göz önünde bulundurulmalıdır. Ders kitaplarının farklı ortamlarda öğrencinin sürekli yanında olduğuna vurgu yapan Arı'ya (2014) göre bu kitaplar kapağıyla, ağırlığıyla, kâğıt ve karton kalitesiyle, cildiyle, boyutuyla, kullanışlılık ve dayanıklılık özellikleriyle gerekli fiziksel niteliklere sahip olmalıdır. Ders kitabının, biçim ve içerik açısından bilgi yüklü grafiksel tasarım ürünü olduğunu belirten İşeri (2007) de kitaplara seçilen metinlerin resimlenmesi ve eğitsel açıdan tasarımlanmasının önem kazandığına dikkat çekmektedir. Duman ve Çakmak (2004) bir ders kitabında yer 
alacak konuların bir bütünlük içinde, diğer disiplinlerle ilişkilendirilerek ve bunu yaparken içeriğe uygun öğretim yöntem ve stratejileri kullanılarak yapılmasının gerekli olduğuna vurgu yapmaktadır. Şahin'e (2012) göre ise etkili bir ders kitabının öğrenciye verilmek istenen mesajı en kısa yoldan, açık ve anlaşılır biçimde iletmesi gerekir. Zira mesaj tasarım ilkelerine uygun şekilde hazırlanan bir ders kitabı öğrenme ve öğretme sürecinde daha işlevsel olacaktır.

İçinde bulunduğumuz çağda dünya üzerindeki ülkeler arasında kültürel, siyasal, bilimsel, ticari vb. ilişkiler her geçen gün artarak ilerlemektedir. Ülkeler arası ilişkilerin gelişmesinin bir sonucu olarak günümüzde yabancı dil bilmek temel bir gereksinim hâlini almıştır (Büyükikiz, 2014). Bu nedenle yabancı dillerin öğretimi ve öğrenimi her geçen gün hız kazanmaktadır. Küreselleşmeyle birlikte, kültürler ve uluslararası ilişkiler geliştikçe Türkçe de birçok alanda yaygın bir şekilde kullanılmaya ve öğrenilmeye başlanmıştır. Buna bağlı olarak Türkçenin yabancı dil olarak öğrenimi ve öğretimi de hızla yaygınlaşmaktadır (Karababa \& Üstünsoy Taşkın, 2012; Kurt, Direkci \& Caner, 2018). Günümüzde birçok ülkeden çok sayıda insan çeşitli sebeplerle Türkçe öğrenmek için hem ülkemize gelmekte hem de yurt dışındaki Türkçe öğretim merkezlerinde Türkçe öğrenmektedir. Geçmişten beri birçok yabancının öğrendiği Türkçenin uluslararası tanınırlığının ve işlevselliğinin artmasıyla bu süreç daha da hızlanmıştır (Biçer, 2017). Akın'a (2016) göre bu merkezlerde Türkçe öğrenen her birey hem Türkçenin hem de ülkemizin birer elçisi konumundadır. Bu durumda Türkçeyi daha etkili ve doğru öğretmek bu alanla ilgilenen herkes için önemli bir görevdir.

Yabancılara, Türkçeyi daha iyi öğretmek için çağdaş yaklaşım ve yöntemlerle eğitim programları hazırlanmakta ve bu doğrultuda amaçlar belirlenmektedir (Yılmaz \& Temiz, 2014). Türkçenin yabancı dil olarak öğretiminde görev alacak olanların bu alandaki başarısında ve bu amaçlara ulaşılmasında kullanılacak ders materyallerinin önemli bir yeri vardır. Zira materyaller birçok duyu organını harekete geçirebilmekte ve bunlar aracılığıyla öğrenme yaşantılarını zenginleştirme gücüne sahiptir. Bu yaşantı zenginliği sayesinde öğrencilerin öğrenme etkinliklerine daha fazla ilgi ve istek duymalarının önü açılabilir (Biçer, 2019). Özdemir'e (2013) göre yabancılara Türkçe öğretimi alanında kullanılmak üzere hazırlanacak ders materyalleri, yazarlarının Türkçe ve Türkçenin öğretimi konusunda sahip oldukları görüşlerin izlerini taşıyacağından bu ders malzemeleri, Türkçe öğretiminde takip edilecek müfredatın belirlenmesi ve sınırlandırılması açısından da önemli bir rol oynayacaktır. $\mathrm{Bu}$ sebeple bu materyallerin yazarları/hazırlayıcıları, öğrenme ve öğretme tekniklerine ve bu malzemeleri kullanacakların şartlarına aşina olmalı, başarıyla uygulanabilecek bir içerik sunabilmelidir.

Öğretim programlarının taşıyıcısı konumundaki ders kitapları (Serin \& Turan, 2015: 1231) "eğitimin her kademesinde olduğu gibi yabancılara Türkçe öğretiminde de en çok kullanılan önemli materyallerden biridir. Türkçenin yabancı dil olarak öğretimi için hazırlanan kitaplarda okuma, yazma, dinleme ve konuşma becerileri ile dil bilgisi öğrenme alanı dikkate alınarak yabancıların bu becerileri geliştirmesi amaçlanmaktadır" (Biçer \& Alan, 2017: 1130). Dil öğretiminde çeşitli yaklaşımlardan hareketle ve farklı amaçlara yönelik olarak hazırlanan bu kitaplar seviyelere uygun okuma metinleri, görseller ve etkinliklerden oluşmaktadır (Tok, 
2013). Öğrencilerin metinlerle karşılaşmasının yabancı dil öğretiminde büyük oranda sınıf ortamı ve ders materyalleri ile sınırlı olduğunu belirten Serin ve Turan'a (2015: 1231) göre "yabancı dil öğretimi kitaplarında yer verilen metinlerin seçiminde ana dili öğretimi kitaplarına oranla daha titiz davranılmalı, derste kullanılacak metinlerin hedef kitlenin seviyesine ve dersin amaçlarına uygun olmasına, Türkçenin özelliklerini ve kültürel değerleri yansıtmasına, öğrencinin hayatta karşılaşabileceği bilgileri içererek onlara gerçeğe yakın bir ortam hazırlamasına çalışılmalıdır.” Lüle Mert'e (2013: 152) göre “bu kitapların Türkçenin kullanım olanaklarından doğru ve yeterli düzeyde yararlanması öğretimi amaçlanan dilin her türlü özelliğini öğrenciye kazandırır ve tanıtır nitelikte olması" gerekirken Tiryaki ve Doğan (2017: 505), "yabancı dil öğretimi için hazırlanan kitapların temel amacının Türkçe öğretimi olsa da bu kitapların Türkçenin zenginliklerini, Türk kültürünü ve çeşitli bilgileri de yeterince ihtiva etmesi” gerektiğini vurgulamaktadır.

\section{Araştırmanın Amacı}

Yabancı dil olarak Türkçe öğretimi üzerine yapılan araştırmaların eğilimlerini çeşitli açılardan incelemeyi amaçlayan çalışmalarda ders kitaplarının ön plana çıktığ görülmektedir. Ercan'ın (2015) 1989-2013 yılları arasında tamamlanmış ve yabancılara Türkçe öğretimi üzerine hazırlanmış tezleri incelediği çalışmasında ders kitapları, araştırmacıların örneklem tercihinde ilk sırada $(\% 29,66)$ yer almıştır. 19852017 yılları arasında hazırlanan tezleri ele alan Türkben (2018) de araştırmaların konu dağılımında ders kitabı incelemelerinin ilk sirada $(\% 20,36)$ olduğunu vurgulamıştır. Baki (2019) tarafindan gerçekleştirilen ve yabancılara Türkçe öğretimiyle ilgili yüksek lisans ve doktora düzeyindeki araştırmaların (1994-2017) incelendiği çalışmada tezlerin örneklem düzeyine göre dağılımında dokümanlar \%51,28 ile ilk sırada yer almıştır. 2009-2019 yılları arasında yabancılara Türkçe öğretimi alanında hazırlanmış olan tezleri inceleyen Çelebi, Ergül, Usta ve Mutlu'nun (2019) araştırmasında tezlerin hedef kitlesinde ders kitaplarının ilk sirada $(\% 34,5)$ yer aldığı ortaya çıkmıştır. Yabancılara Türkçe öğretimi alanında 19812012 yılları arasında hazırlanan tezleri değerlendiren Büyükikiz (2014) bu alanda en çok çalışılan beş konudan ikincisinin ders kitaplarının incelenmesi olduğunu ifade etmiştir. Benzer bir çalışmada yabancılara Türkçe öğretimi alanındaki makaleleri (2010-2016) ele alan Biçer (2017), araştırmaların konu alanlarına göre dağılımında ders kitaplarının 23 konu başlığı içerisinde 2. sırada yer aldığını tespit etmiştir. Bağcı Ayrancı'nın (2019) yabancılara Türkçe öğretiminde kültür aktarımı üzerine yapılan lisansüstü tezleri incelediği araştırmada örnekleme alınan çalışmaların \%50'sinin ders kitapları üzerine yapıldığı belirlenmiştir. Bu bulgular, yabancı dil olarak Türkçe öğretimi üzerine çalışan araştırmacılar için ders kitaplarının önemli bir veri kaynağı olduğunu göstermektedir. Bu sebeple Yabancı Dil Olarak Türkçe Öğretimi (YDOTÖ) ders kitapları üzerine yapılan araştırmaların daha geniş bir çerçevede ele alınıp incelenmesinin yararlı olacağı düşünülmektedir. Böyle bir düşünceden hareketle gerçekleştirilen bu çalışmanın araştırma soruları alt problemler doğrultusunda aşağıdaki şekilde oluşturulmuştur:

1. Yabancı dil olarak Türkçe öğretimi ders kitapları üzerine yapılan araştırmaların yayın türlerine (makale/tez) göre dağılımı nasıldır? 
2. Yabancı dil olarak Türkçe öğretimi ders kitapları üzerine yapılan araştırmaların yıllara göre (2010-2020) dağılımı nasıldır?

3. Yabancı dil olarak Türkçe öğretimi ders kitapları üzerine yapılan tezlerin öğrenim kademesine (yüksek lisans/doktora) göre dağılımı nasıldır?

4. Yabancı dil olarak Türkçe öğretimi ders kitapları üzerine yapılan tezlerin hazırlandıkları üniversitelere göre dağılımı nasıldır?

5. Yabancı dil olarak Türkçe öğretimi ders kitapları üzerine yapılan tezlerin danışman unvanlarına göre dağılımı nasıldır?

6. Yabancı dil olarak Türkçe öğretimi ders kitapları üzerine yapılan makalelerin yazar sayılarına göre dağılımı nasıldır?

7. Yabancı dil olarak Türkçe öğretimi ders kitapları üzerine yapılan araştırmaların örneklem seçimine göre dağılımı nasıldır?

8. Yabanc1 dil olarak Türkçe öğretimi ders kitapları üzerine yapılan araştırmaların kur düzeyine göre dağılımı nasıldır?

9. Yabancı dil olarak Türkçe öğretimi ders kitapları üzerine yapılan araştırmaların konu seçimine göre dağılımı nasıldır?

\section{Yöntem}

Araştırmanın modeli, örneklemi, verilerin toplanması ve analiz süreci gibi bilgilere bu başlık altında yer verilmiştir.

\section{Araștırma Modeli}

Yabancı dil olarak Türkçe öğretimi ders kitapları üzerine yapılan araştırmaların eğilimlerini tespit etmeyi amaçlayan bu çalışma nitel araştırma deseninde doküman incelemesiyle yürütülmüştür. Baş ve Akturan'a (2017) göre bir çalışmada araştırma problemlerine ilişkin olarak yazılı ve görsel dokümanların başvurulması daha zengin ve kapsamlı bir çıkarım sağlanması açısından önemlidir. Yazılı veya görsel malzemenin toplanıp incelenmesi olarak tanımlanabilecek bu yöntemde araştırmacının neyi, neden, niçin, nasıl ve nerede arayacağını bilmesi önem taşımaktadır (Sönmez \& Alacapınar, 2019).

\section{Evren ve Örneklem}

$\mathrm{Bu}$ araştırmada amaçlı örnekleme çeşitlerinden ölçüt örnekleme tercih edilmiştir. Yıldırım ve Şimşek'e (2011) göre bu örnekleme yöntemindeki temel anlayış önceden belirlenmiş bir dizi ölçütü karşılayan bütün durumların çalışılmasıdır. "Doküman incelemesi tekniğinin kullanıldığı", örneklemi "yabancı dil olarak Türkçe öğretimi ders kitapları" olan, "2010-2020 yılları arasında yayımlanan" ve "makale veya tez olarak hazırlanan" araştırmalar bu çalışmada ölçüt olarak alınmıştır.

Araştırmanın evrenini yabancı dil olarak Türkçe öğretimi ders kitaplarını inceleyen bilimsel çalışmalar oluşturmaktadır. Araştırmanın örneklemi ise bu konuda 2010-2020 yılları arasında hazırlanan lisansüstü tezler ve makalelerdir. YÖK Tez Merkezi üzerinden ulaşılan tezler ile YÖK Akademik, Google Scholar ve Dergipark veri tabanları üzerinden ulaşılan makaleler çalışmaya dâhil edilmiştir. Dil öğretimini desteklemek amacıyla hazırlanan okuma kitapları ise kapsam dişında bırakılmıştır.

\section{Veri Toplama ve Analiz Süreci}


Araştırmada incelenen makale ve tezlere 2020 yılı Ekim ayının ikinci yarısında erişilmiştir. Tezler için YÖK Ulusal Tez Merkezi, makaleler için çeşitli veri tabanları (YÖK Akademik, Google Scholar ve Dergipark) kullanılmış, "yabancı dil olarak/yabancılara Türkçe öğretimi”, "yabancı dil olarak/yabancılara Türkçe öğretimi ders kitabı/ders kitapları" ve "ders kitabı/kitapları" anahtar kelimeleri/kelime grupları kullanılarak yapılan taramalar neticesinde elde edilen araştırmalar, çalışmada kullanılmak üzere bilgisayar ortamında dosyalanmıştır. Tezlerden yalnızca yazarları tarafından erişim izni verilenler araştırmaya katılmış, tezden üretilmiş makalelerin de sadece tez yayınları kullanılmıştır. Bu tezleri ve makaleleri değerlendirmek üzere araştırmacı tarafindan, kapsam geçerliğini sağlamak amacıyla uzman görüşü (Türkçe eğitimi alanında çalışan bir doktor öğretim üyesi ve ölçme değerlendirme alanında çalışan bir doktor öğretim üyesi) de alınarak araştırma sorularına uygun şekilde bir yayın sınıflandırma formu oluşturulmuştur. $\mathrm{Bu}$ form tezler için ayrı (yıl, ögrenim kademesi, üniversite, danışman unvanı, örneklem, kur düzeyi, konu başlıkları altında), makaleler için ayrı (yıl, yazar sayısı, örneklem, kur düzeyi, konu başlıkları altında) olmak üzere iki nüsha şeklinde düzenlenmiş, tezlerin ve makalelerin incelenmesi neticesinde ulaşılan veriler bu formlara işlenmiştir.

Elde edilen verilerin analizinde içerik analizi tekniğinden yararlanılmıştır. "Belirli kurallara dayalı kodlamalarla bir metnin bazı sözcüklerinin daha küçük içerik kategorileri ile özetlendiği sistematik, yinelenebilir bir teknik" (Büyüköztürk, Kılıç-Çakmak, Akgün, Karadeniz ve Demirel, 2020: 259) olarak tanımlanan bu analiz tekniğinde yapılan temel işlem, "birbirine benzeyen verileri belirli kavramlar ve temalar çerçevesinde bir araya getirmek ve bunları okuyucunun anlayabileceği bir biçimde düzenleyerek yorumlamaktır" (Yıldırım \& Şimşek, 2011: 227). Araştırmaya dâhil edilen bilimsel çalışmalar yayın yılı, örneklem, kur düzeyi ve konu seçimi, tezlerin öğrenim kademesi, hazırlandıkları üniversiteler, danışman unvanları ve makalelerin yazar sayısı temaları bakımından tasnif edilmiş, bu temalara göre elde edilen bulgular sıklık (f) ve yüzde (\%) değerleri hesaplanarak tablolar ve grafikler aracılığılla sunulmuştur.

\section{Geçerlik ve Güvenirlik}

Tüm araştırmaların temel unsurları olarak bilinen geçerlik ve güvenirlik nicel çalışmalarda olduğu gibi nitel çalışmalar açısından da çok önemlidir (Batdı \& Oral, 2020). Yıldırım ve Şimşek'e (2011) göre nitel bir araştırmada toplanan verilerin ayrıntılı olarak rapor edilmesi ve araştırmacının sonuçlara nasıl ulaştığını açıklaması geçerliğin önemli ölçütleri arasındadır. $\mathrm{Bu}$ sebeple çalışmanın raporlaştırılması aşamasında araştırmacı tarafindan bulguların detaylı şekilde aktarılması ve metintablo-grafik uyumunun gözden geçirilmesiyle araştırmanın geçerliği sağlanmaya çalışılmıştır. Ayrıca araştırmanın dış güvenirliğini sağlamada veri toplama ve analiz yöntemleri ile ilgili ayrıntılı açıklamaların yapılması önemli (Yıldırım \& Şimşek, 2011) görüldüğünden yöntem bölümünde bu süreç hakkında da bilgilendirme yapılmıştır.

Nitel bir araştırmanın iç güvenirliğini sağlamada başvurulacak stratejilerden biri de elde edilen verilerin analizinde başka bir araştırmacıyı kullanma ve böylelikle 
sonuçları teyit etmedir (Yıldırım \& Şimşek, 2011). Bu süreç araştırmacının, araştırma analizlerini ve sonuçlarını incelemek ve yorumların gerçeği yansıtıp yansıtmadığını anlamak amacıyla kendi meslektaşı olan başka bir araştırmacıya sunması ve onun düşüncelerini almasını içerir (Ekiz, 2020). Çalışma kapsamında incelenen araştırmaların "konu" başlığı dişındakiler tez ve makalelerde net bir şekilde ifade edildiğinden sinıflandırma formundaki "konu" başlığı için başka bir uzmanın (Türkçe eğitimi alanında çalışan bir doktor öğretim üyesi) da değerlendirme yapmasının uygun olacağı düşünülmüş ve kodlayıcılar arası uyuma bakılmıştır. Miles ve Huberman formülünün [Güvenirlik= Görüş birliği/(görüş birliği+görüş ayrılığı)x 100] kullanıldığı işlem neticesinde bu uyumun \%91 olduğu görülmüştür. Güvenirlik hesaplarının \%70'in üzerinde çıkması, araştırma için güvenilir kabul edildiğinden (Miles \& Huberman, 1994) ulaşılan sonuçların güvenilir olduğu düşünülmektedir.

Araştırmanın yazım sürecinde bilimsel, etik ve alıntı kurallarına uyulmuş, toplanan veriler üzerinde herhangi bir tahrifat yapılmamıştır.

\section{Bulgular ve Yorum}

Çalışmanın bu bölümünde araştırma soruları doğrultusunda elde edilen bulgulara değinilmiştir.

\section{Birinci Araştırma Sorusuna Yönelik Bulgular}

Araştırmanın "Yabancı dil olarak Türkçe ögretimi ders kitapları üzerine yapılan araştırmaların yayın türlerine (makale/tez) göre dă̆llımı nasıldır?" ş̧eklindeki birinci sorusuna yönelik bulgulara Grafik 1'de yer verilmiştir.

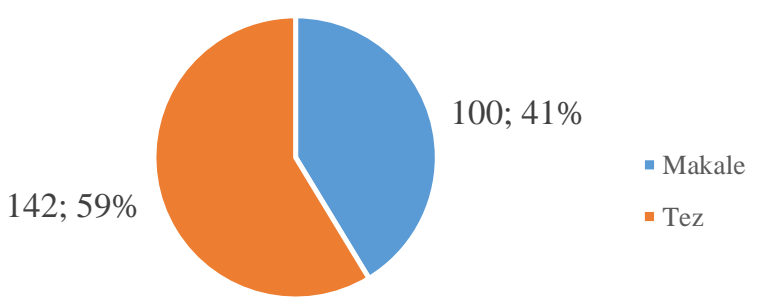

Grafik 1. YDOTÖ ders kitapları üzerine yapılan araştırmaların yayın türlerine göre dağılımı

Grafik 1'de görüldüğü gibi YDOTÖ ders kitapları üzerine yapılan 242 bilimsel faaliyetin 142’si (\%59) lisansüstü tez, 100’ü (\%41) ise makale olarak hazırlanmıştır.

\section{İkinci Araştırma Sorusuna Yönelik Bulgular}

Araştırmanın "Yabancı dil olarak Türkçe ögretimi ders kitapları üzerine yapılan araştırmaların yıllara göre (2010-2020) dağılımı nasıldır?" şeklindeki ikinci sorusuna yönelik bulgulara Grafik 2'de yer verilmiştir. 


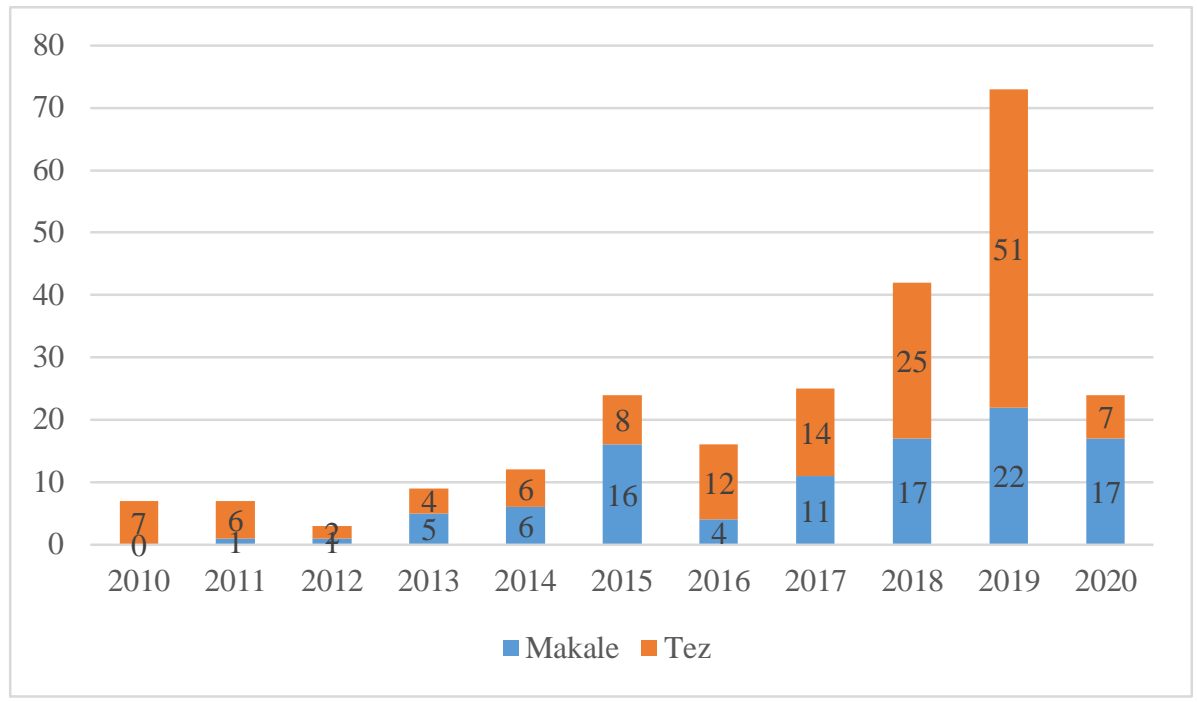

Grafik 2. YDOTÖ ders kitapları üzerine yapılan araştırmaların yıllara göre dağılımı

Grafik 2'ye göre YDOTÖ ders kitapları üzerine yapılan araştırmaların en fazla 2019'da yapıldığı belirlenmiştir. Bu yılda 22'si makale, 51'i tez olmak üzere 73 $(\% 30,16)$ çalışma gerçekleştirilmiştir. 2018 senesi de bu konudaki çalışmaların yoğun olduğu bir dönem olmuştur. İlgili yılda 17'si makale, 25'i tez olmak üzere 42 araştırma ortaya çıkmıştır. Konuyla ilgili olarak 2017'de 25; 2015 ve 2020'de 24; 2016'da 16; 2014'te 12 araştırmanın olduğu görülürken 2013 (f=9), 2010, 2011 $(\mathrm{f}=7)$ ve $2012(\mathrm{f}=3)$ yılları araştırma sayısının daha az olduğu dönemler olarak tespit edilmiştir.

\section{Üçüncü Araştırma Sorusuna Yönelik Bulgular}

Araştırmanın "Yabancı dil olarak Türkçe ögretimi ders kitapları üzerine yapılan tezlerin ögrrenim kademesine (yüksek lisans/doktora) göre dă̆ılımı nasıldır?" şeklindeki üçüncü sorusuna yönelik bulgular Tablo 1'de gösterilmiştir.

Tablo 1.

YDOTÖ Ders Kitapları Üzerine Yapılan Tezlerin Öğrenim Kademesine Göre Dağılımı

\begin{tabular}{cccc}
\hline Öğrenim Kademesi & Yüksek Lisans & Doktora & Toplam \\
\hline $\mathrm{f}$ & 132 & 10 & 142 \\
\hline$\%$ & $\% 93$ & $\% 7$ & $\% 100$ \\
\hline
\end{tabular}

Tablo 1'de görüldüğü gibi YDOTÖ ders kitapları üzerine hazırlanan 142 tezin 132'si (\%93) yüksek lisans, 10'u (\%7) ise doktora düzeyinde hazırlanan tezlerden oluşmaktadır.

\section{Dördüncü Araştırma Sorusuna Yönelik Bulgular}


Araştırmanın "Yabancı dil olarak Türkçe ögretimi ders kitapları üzerine yapılan tezlerin hazırlandıkları üniversitelere göre dağılımı nasıldır?" şeklindeki dördüncü sorusuna yönelik bulgular Tablo 2'de gösterilmiştir.

Tablo 2.

YDOTÖ Ders Kitapları Üzerine Yapılan Tezlerin Hazırlandıkları Üniversitelere Göre Dağılımı

\begin{tabular}{lc}
\hline Üniversite Adı & f \\
\hline İstanbul Üniversitesi & 22 \\
Hacettepe Üniversitesi & 14 \\
Gazi Üniversitesi & 13 \\
Dokuz Eylül Üniversitesi & 11 \\
Nevşehir Hacı Bektaş Veli Üniversitesi & 10 \\
Çanakkale Onsekiz Mart Üniversitesi & 8 \\
Tokat Gaziosmanpaşa Üniversitesi & 7 \\
Sakarya Üniversitesi & 5 \\
Ankara Üniversitesi & 4 \\
Yıldız Teknik Üniversitesi & 4 \\
Ondokuz Mayıs Üniversitesi & 3 \\
Başkent Üniversitesi & 3 \\
Akdeniz Üniversitesi & 3 \\
Zonguldak Bülent Ecevit Üniversitesi & 3 \\
Gaziantep Üniversitesi & 3 \\
Bursa Uludağ Üniversitesi & 3 \\
Marmara Üniversitesi & 3 \\
Çukurova Üniversitesi & 2 \\
Karadeniz Teknik Üniversitesi & 2 \\
Atatürk Üniversitesi & 2 \\
Fırat Üniversitesi & 2 \\
Hatay Mustafa Kemal Üniversitesi & 2 \\
Bolu Abant İzzet Baysal Üniversitesi & 2 \\
Diğer & 2 \\
\hline Toplan & 2 \\
\hline & 2 \\
\hline & 2 \\
\hline & 2 \\
\hline & 2 \\
\hline & 2 \\
\hline
\end{tabular}

$\begin{array}{ll}\text { Toplam } & 142\end{array}$

Tablo 2'ye göre YDOTÖ ders kitapları üzerine hazırlanan tezlerin en fazla İstanbul Üniversitesi ( $\mathrm{f}=22)$, Hacettepe Üniversitesi $(\mathrm{f}=14)$, Gazi Üniversitesi ( $\mathrm{f}=13)$, Dokuz Eylül Üniversitesi $(\mathrm{f}=11)$ ve Nevşehir Hac1 Bektaş Veli Üniversitesi $(\mathrm{f}=10)$ bünyesinde hazırlandığ 1 ortaya çıkmıştır. Çanakkale Onsekiz Mart Üniversitesi $(\mathrm{f}=8)$, Tokat Gaziosmanpaşa Üniversitesi $(\mathrm{f}=7)$ ve Sakarya Üniversitesi $(\mathrm{f}=5)$ de ders kitapları üzerine yapılan çalışmalarda ön plana çıkan kurumlardandır. Bunların dışında konuyla ilgili olarak Ankara Üniversitesi ile Yıldız Teknik Üniversitesinde dörder; Ondokuz Mayıs Üniversitesi, Başkent Üniversitesi, Akdeniz Üniversitesi, Zonguldak Bülent Ecevit Üniversitesi, Gaziantep Üniversitesinde üçer; 
Bursa Uludağ Üniversitesi, Marmara Üniversitesi, Çukurova Üniversitesi, Karadeniz Teknik Üniversitesi, Atatürk Üniversitesi, Fırat Üniversitesi, Hatay Mustafa Kemal Üniversitesi, Bolu Abant İzzet Baysal Üniversitesinde de ikişer çalışmanın hazırlandığı tespit edilmiştir. "Diğer" kategorisindeki 13 kurumda da birer çalışmanın gerçekleştirildiği belirlenmiştir.

\section{Beşinci Araştırma Sorusuna Yönelik Bulgular}

Araştırmanın "Yabancı dil olarak Türkçe ögrretimi ders kitapları üzerine yapılan tezlerin danışman unvanlarına göre dağılımı nasıldır?” şeklindeki beşinci sorusuna yönelik bulgular Tablo 3'te gösterilmiştir.

Tablo 3.

YDOTÖ Ders Kitapları Üzerine Yapılan Tezlerin Danışman Unvanlarına Göre Dağılımı

\begin{tabular}{ccccc}
\hline Unvan & Prof. Dr. & Doç. Dr. & $\begin{array}{c}\text { Dr. Öğr. Üyesi/ } \\
\text { Yrd. Doç. Dr. }\end{array}$ & Toplam \\
\hline $\mathrm{f}$ & 52 & 51 & 39 & 142 \\
\hline$\%$ & $\% 37$ & $\% 36$ & $\% 27$ & $\% 100$ \\
\hline
\end{tabular}

Tablo 3'te görüldüğü üzere YDOTÖ ders kitapları üzerine hazırlanan tezlerin en fazla Prof. Dr. (f=52, \%37) ve Doç. Dr. ( $f=51, \% 36)$ unvanına sahip öğretim üyeleri danışmanlığında hazırlandığı belirlenmiştir. 39 tez (\%27) ise Dr. Öğr. Üyesi/Yrd. Doç. Dr. unvanına sahip öğretim üyelerinin danışmanlığında yürütülmüştür.

\section{Altıncı Araştırma Sorusuna Yönelik Bulgular}

Araştırmanın "Yabancı dil olarak Türkçe ögrretimi ders kitapları üzerine yapılan makalelerin yazar sayılarına göre dă̆llımı nasıldır?" şeklindeki altıncı sorusuna yönelik bulgular Tablo 4'te gösterilmiştir.

Tablo 4.

YDOTÖ Ders Kitapları Üzerine Yapılan Makalelerin Yazar Sayllarına Göre Dağılımı

\begin{tabular}{ccccc}
\hline Yazar Sayısı & Tek yazarlı & Çift yazarlı & $\begin{array}{c}\text { Üç ve daha fazla } \\
\text { yazarlı }\end{array}$ & Toplam \\
\hline $\mathrm{f}$ & 43 & 46 & 11 & 100 \\
\hline$\%$ & $\% 43$ & $\% 46$ & $\% 11$ & $\% 100$ \\
\hline
\end{tabular}

Tablo 4'e göre YDOTÖ ders kitapları üzerine yazılan 100 makalenin 46's1 2 yazarlı makale iken 43'ü tek yazarlı makale şeklindedir. 3 ve daha fazla yazarlı makale sayısı ise $11^{\prime}$ 'dir.

\section{Yedinci Araştırma Sorusuna Yönelik Bulgular}

Araştırmanın "Yabancı dil olarak Türkçe ögretimi ders kitapları üzerine yapılan araştırmaların örneklem seçimine göre dağılımı nasıldır?" şeklindeki yedinci sorusuna yönelik bulgular Tablo 5 'te gösterilmiştir. 
Tablo 5 .

YDOTÖ Ders Kitapları Üzerine Yapılan Araştırmaların Örneklem Seçimine Göre Dağılımı

\begin{tabular}{lccc}
\hline \multicolumn{1}{c}{ Eser Adı } & Makale (f) & Tez (f) & Toplam (f) \\
\hline Yeni Hitit Yabancılar İçin Türkçe & 36 & 84 & 120 \\
İstanbul Yabancılar İçin Türkçe & 41 & 67 & 108 \\
Yedi İklim Yabancılar İçin Türkçe & 39 & 66 & 105 \\
Gazi Yabancılar İçin Türkçe & 28 & 54 & 82 \\
İzmir Yabancılar İçin Türkçe & 9 & 17 & 26 \\
Lale Türkçe Öğretim Seti & 5 & 4 & 9 \\
Türkçe Öğreniyorum & 5 & 3 & 8 \\
Yabancı Dilim Türkçe & 3 & 4 & 7 \\
Diğer & 12 & 14 & 26 \\
\hline
\end{tabular}

Tablo 5'te görüldüğü gibi Yeni Hitit Yabancllar İçin Türkçe Öğretim Seti 36 makale, 84 tez olmak üzere 120 araştırmada örneklem olarak seçilerek ilk sırada yer almıştır. İstanbul Yabancılar İçin Türkçe Öğretim Seti 41 makale, 67 tez olmak üzere toplam 108; Yedi Iklim Yabancılar Iç̧in Türkçe Öğretim Seti 39 makale, 66 tez olmak üzere toplam 105; Gazi Yabancılar Iç̧in Türkçe Ögrretim Seti de 28 makale, 54 tez olmak üzere toplam 82 araştırmada örnekleme alınarak araştırmacılar tarafından üzerinde en fazla inceleme yapılan kitaplar olmuştur. İzmir Yabancılar İçin Türkçe Ögretim Seti de 9 makale ve 17 tezde örnekleme alınmıştır. Bunların dışında Lale Türkçe Öğretim Seti (f=9), Türkçe Öğreniyorum (f=8), Yabancı Dilim Türkçe $(\mathrm{f}=7)$ kitapları ile "Diğer" kategorisi altında yer verilen $(\mathrm{f}=26)$ kitapların da örneklem olarak tercih edildiği araştırmaların mevcut olduğu görülmektedir.

\section{Sekizinci Araştırma Sorusuna Yönelik Bulgular}

Araştırmanın "Yabancı dil olarak Türkçe ögretimi ders kitapları üzerine yapılan araştırmaların kur düzeyine göre dağllımı nasıldır?" şeklindeki sekizinci sorusuna yönelik bulgular Tablo 6' da gösterilmiştir.

Tablo 6.

YDOTÖ Ders Kitapları Üzerine Yapılan Araştırmalartn Kur Düzeyine Göre Dağılımı

\begin{tabular}{ccccc}
\hline Kur Düzeyi & Makale (f) & Tez (f) & Toplam (f) & $\%$ \\
\hline Temel Düzey Kitaplar & 68 & 107 & 175 & $\% 72,31$ \\
Orta Düzey Kitaplar & 52 & 96 & 148 & $\% 61,15$ \\
İleri Düzey Kitaplar & 42 & 71 & 113 & $\% 46,69$ \\
\hline
\end{tabular}

Tablo 6'ya göre YDOTÖ ders kitapları üzerine yapılan araştırmaların kur düzeyine göre dağılımına bakıldığında en fazla ( $\mathrm{f}=175, \% 72,31)$ temel düzey öğrenciler için hazırlanan kitapların örnekleme alındığı görülmektedir. Bu düzey için hazırlanan kitaplar 100 makalenin 68'inde, 142 tezin de 107'sinde incelemeye alınmıştır. Orta düzey öğrenciler için hazırlanan ders kitapları 52 makale, 96 tez olmak üzere $148(\% 61,15)$ araştırmanın örneklemini oluştururken ileri düzey 
öğrenciler için hazırlanan kitaplar 42'si makale, 71'i tez olmak üzere $113(\% 46,69)$ çalışmada araştırmacılar tarafindan örneklem olarak tercih edilmiştir.

\section{Dokuzuncu Araştırma Sorusuna Yönelik Bulgular}

Araştırmanın "Yabancı dil olarak Türkçe ögretimi ders kitapları üzerine yapılan araştırmaların konu seçimine göre dağılımı nasıldır?" şeklindeki dokuzuncu sorusuna yönelik bulgular Tablo 7'de gösterilmiştir.

Tablo 7.

YDOTÖ Ders Kitapları Üzerine Yapılan Araştırmaların Konu Seçimine Göre Dă̆llımı

\begin{tabular}{lccc}
\hline Konular & Makale (f) & Tez (f) & Toplam (f) \\
\hline Söz varlığı, kelime öğretimi & 17 & 38 & 55 \\
Kültürel unsurlar, kültür aktarımı & 25 & 26 & 51 \\
Temel dil becerileri & 16 & 22 & 38 \\
Dil bilgisi & 11 & 26 & 37 \\
Metin türleri & 7 & 12 & 19 \\
Yöntem, teknik ve stratejiler & 7 & 9 & 16 \\
Değerler eğitimi & 4 & 3 & 7 \\
Görsel ögeler & 5 & 2 & 7 \\
Metin altı soruları & 1 & 5 & 6 \\
Okunabilirlik & 4 & 1 & 5 \\
Seviyeye uygunluk & 2 & - & 2 \\
Metinsellik & 2 & - & 2 \\
\hline
\end{tabular}

Tablo 7'de görüldüğü üzere YDOTÖ ders kitapları üzerine yapılan araştırmalarda en fazla "söz varlığ1/kelime öğretimi” (f=55) ve "kültürel unsurlar/kültür aktarımı” (f=51) konularının çalışıldığı görülmektedir. "Söz varlığı/kelime öğretimi” tezlerde ( $\mathrm{f}=38)$, "kültürel unsurlar/kültür aktarımı" ise makalelerde $(\mathrm{f}=25)$ en fazla çalışılan konu olmuştur. Araştırmalarda temel dil becerilerine yönelik etkinliklerin incelenmesi $(\mathrm{f}=38)$ ve dil bilgisi etkinlikleri $(\mathrm{f}=37)$ araştırmacıların yoğun olarak inceleme yaptıkları diğer iki konu olarak öne çıkmıştır. Bununla beraber kitaplardaki metinlerin türleri $(\mathrm{f}=19)$, çeşitli yöntem ve tekniklerin kitaplarda yer alma durumlarının $(\mathrm{f}=16)$ ele alınması dışında değerler eğitimi ( $f=7)$, görsel ögeler $(f=7)$, metin altı sorularının incelenmesi $(f=6)$, okunabilirlik $(\mathrm{f}=5)$, seviyeye uygunluk $(\mathrm{f}=2)$ ve metinsellik ölçütleri konularında da çalışmaların yapıldığı görülmektedir.

\section{Tartışma ve Sonuç}

$\mathrm{Bu}$ araştırmada yabancı dil olarak Türkçe öğretimi ders kitaplarının incelendiği makale ve tezlerin çeşitli yönlerden ele alınması amaçlanmış, ulaşılan sonuçlara ve bu sonuçların alanyazındaki farklı çalışmalarla ilişkisine aşağıda değinilmiştir.

Yabancı dil olarak Türkçe öğretimi ders kitapları üzerine yapılan bilimsel çalışmaların daha çok lisansüstü tez $(\% 59)$ olarak karşımıza çıktığı, makalelerin 
toplam yayınlar içindeki oranının \%41 olduğu görülmektedir. Çiftçi ve Coşkun'un (2017) yabancılara Türkçe öğretimi alanındaki çalışmaları tasnif ettikleri araştırmada ise 235 tez, 270 makale tespit edilmiştir. Buna göre yabancilara Türkçe öğretimi çalışmalarında makaleler daha fazla gibi görünse de örneklemi ders kitapları olan araştırmaların daha çok tez çalışması şeklinde olduğunu söylemek mümkündür. Yine bilindiği üzere "tezden makale üretme", bilimsel yayınlarda araştırmacıların tercih ettikleri uygulamalardan biridir. $\mathrm{Bu}$ araştırmada tezlerden makaleye dönüştürülmüş olan bir çalışmanın yalnızca tez yayını dikkate alınmıştır. Bundan dolayı bu özellikteki makalelerin çalışma dışında bırakılmasının da bu sonuçta etkili olduğu düşünülmektedir.

Yabancı dil olarak Türkçe öğretimi ders kitapları üzerine yapılan araştırmaların yayın yıllarına bakıldığında en fazla çalışmanın 2019 yılında $(\mathrm{f}=73)$ yapıldığ belirlenmiştir. Bununla birlikte 2018 ( $\mathrm{f}=42), 2017$ ( $\mathrm{f}=25), 2015$ ve 2020 ( $\mathrm{f}=24)$ yılları da yayın sayısının fazla olduğu dönemler olmuştur. 2017-2020 yılları arasındaki son 4 yıllık dönemde yapılan araştırmalar ( $\mathrm{f}=164), 11$ yıllık zaman diliminde (2010-2020) yapılan araştırmaların (f=242) \%67,76'sına karşılık gelmektedir. Araştırma verilerinin 2020 yılı Ekim ayı içerisinde elde edildiği düşünüldüğünde bu yıla ait yayın sayılarının ilerleyen zamanda daha da artış göstereceği tahmin edilmektedir. Yabancılara Türkçe öğretimi araştırmalarını inceleyen yayınlarda da (Baki, 2019; Çelebi vd., 2019; Türkben, 2018) araştırmaların yapıldığı döneme yakın yıllarda yayın sayılarının arttığına yönelik sunulan tespitler, bu çalışmanın sonuçlarını destekler niteliktedir. $\mathrm{Bu}$ da yıllar geçtikçe yabancılara Türkçe öğretimi araştırmalarının daha da önem kazanmaya başladığını göstermektedir.

Yabancı dil olarak Türkçe öğretimi ders kitapları üzerine yapılan lisansüstü tezlerin ( $\mathrm{f}=142)$ öğrenim kademesine göre dağılımına bakıldığında yüksek lisans tezlerinin $(\% 93)$ belirgin şekilde öne çıktığı tespit edilmiştir. Bu sonuç yabancılara Türkçe öğretimi alanındaki lisansüstü tezlerin eğilimlerini araştıran çalışmaların (Baki, 2019; Büyükikiz, 2014; Çelebi vd., 2019; Ercan, 2015; Küçük \& Kaya, 2018; Türkben, 2018) bulgularıyla paralellik göstermektedir. Alandaki yüksek lisans/doktora programı/öğrencisi sayısının bu sonuçta etkili olabileceği, aynı zamanda ders kitabı değerlendirmeleri doküman incelemesi tekniği olduğundan bu tür çalışmaların daha çok yüksek lisans düzeyinde kaldığı düşünülmektedir.

Yabancı dil olarak Türkçe öğretimi ders kitapları üzerine yapılan lisansüstü tezler ( $\mathrm{f}=142$ ) 35 farklı üniversitede hazırlanmıştır. Bu üniversitelerin 13'ünde birer araştırma yapılırken 22'sinde konuyla ilgili en az iki araştırmanın yapıldığı belirlenmiştir. İstanbul Üniversitesi ( $\mathrm{f}=22)$, Hacettepe Üniversitesi $(\mathrm{f}=14)$, Gazi Üniversitesi ( $\mathrm{f}=13$ ), Dokuz Eylül Üniversitesi ( $\mathrm{f}=11$ ) ve Nevşehir Hacı Bektaş Veli Üniversitesi ( $\mathrm{f}=10)$ tez çalışmalarında öne çıkan kurumlar olarak dikkat çekmektedir. Nitekim örnekleme alınan 142 tezin 70'i $(\% 49,29)$ bu beş kurumda hazırlanmıştır. Araştırmanın bu bulgusunun Türkben'in (2018) gerçekleştirdiği ve yabancı dil olarak Türkçe öğretimi alanında lisansüstü düzeyde en fazla araştırmanın Gazi Üniversitesi (\%22,14), İstanbul Üniversitesi $(\% 15,71)$ ve Dokuz Eylül Üniversitesinde (\%15) yapıldığının tespit edildiği araştırmanın bulgularıyla örtüştüğü söylenebilir. Ayrıca bu üç kurum Ercan'ın (2015) araştırmasında da 
yabancı dil olarak Türkçe öğretimi tezlerinde ilk üç sırayı almıştır. $\mathrm{Bu}$ üniversitelerin Türkçe eğitimi alanındaki çalışmalarda da öncü olduğu görülmektedir. Özçakmak'ın (2017) Türkçe eğitimi lisansüstü araştırmalarının eğilimlerini incelediği araştırmasında Gazi Üniversitesi ve Dokuz Eylül Üniversitesinin en fazla tezin hazırlandığı üniversitelerden olduğu belirtilmiştir. Coşkun, Özçakmak ve Balcı (2012) tarafından yapılan ve Türkçe eğitimiyle ilgili olarak 1981-2010 yılları arasında hazırlanan tezlerin incelendiği araştırmada da Gazi Üniversitesi, Hacettepe Üniversitesi ve Dokuz Eylül Üniversitesi en çok tezin hazırlandığı ilk beş kurum arasında yer almıştır. Bunun yanında Gazi Üniversitesi, Türkçe eğitimi doktora tezlerinde (Boyacı \& Demirkol, 2018), dinleme becerisiyle ilgili lisansüstü tezlerde (Doğan \& Özçakmak, 2014) ve Türkçe eğitiminde eylem araştırması yöntemiyle gerçekleştirilen tezlerde (Gülen Canlı \& Tepeli, 2019a) de ilk sırada bulunmaktadır. Türkben'e (2018) göre burada bahsi üniversitelerde gerek Türkçe gerek yabancı dil olarak Türkçe öğretimi lisansüstü programlarının daha önce açılmış olması ve yeterli akademisyenin bulunması, çalışmaların diğer üniversitelere göre fazla olmasında etkili olmuştur.

Yabancı dil olarak Türkçe öğretimi ders kitapları üzerine yapılan lisansüstü tezleri yürüten danışmanların unvanları incelendiğinde "Prof. Dr." (\%37) ve "Doç. Dr." (\%36) unvanına sahip akademik personelin "Dr. Öğr. Üyesi/ Yrd. Doç. Dr." (\%27) unvanına sahip akademik personele oranla konuyla ilgili daha fazla araştırma yaptırdığı görülmektedir. Bu sonuç Bağcı Ayrancı'nın (2019) yabancı dil olarak Türkçe öğretiminde kültür aktarımı üzerine hazırlanan tezlerin danışman bilgileriyle benzerlik göstermektedir. İlgili araştırmada incelenen tezlerin danışmanları en çok $(\% 43,75)$ "Prof. Dr." unvanı taşıyan öğretim üyelerinden oluşmaktadır. Yabancı dil olarak Türkçe öğretimi üzerine hazırlanan tezlerin danışman bilgilerini inceleyen Ercan (2015) da benzer şekilde "Prof. Dr." unvanına sahip danışman sayılarının $(\mathrm{f}=44, \% 37,29)$ ön planda olduğunu tespit etmiştir. Boyacı ve Demirkol (2018) tarafından gerçekleştirilen ve Türkçe eğitimi alanındaki doktora tezlerinin danışman bilgilerine yer verilen araştırmada da tezlerin \%63,5'inin "Prof. Dr." unvanına sahip danışmanlarca yürütüldüğü ifade edilmiştir. Dil bilgisi öğretimi üzerine yapılmış doktora tezlerinin incelendiği başka bir araştırmada da (Gülen Canlı \& Tepeli, 2019b) "Prof. Dr." danışmanlığında yürütülen tez oranı \%48,2 şeklinde ortaya çıkmıştır. Bu sonuçlarda araştırmaların yapıldığı bölümlerdeki unvan dağılımın etkisi olabileceği gibi öğretim üyelerinin çalışma konuları ve uzmanlık alanlarının da etkili olabileceği düşünülmektedir.

Yabancı dil olarak Türkçe öğretimi ders kitapları üzerine yazılan makalelerin yazar sayılarına bakıldığında araştırmacıların çift yazarlı (\%46) veya tek yazarlı (\%43) yayınları daha çok tercih ettikleri ortaya çıkmıştır. Zira örnekleme alınan makalelerin \%89'u en fazla iki yazarlı yayınlardan oluşmuştur. Demir ve Özdemir'in (2017) çalışmasında yabancı dil olarak Türkçe öğretimi üzerine hazırlanan makalelerde tek veya çift yazarlı yayın oranının $\% 88,1$ olduğu tespit edilmiştir. Biçer (2017) de araştırmasında yabancılara Türkçe öğretimi alanında yayımlanan tek veya çift yazarlı makale sayısının toplam araştırmaların \%89,6'sına karşılık geldiğini belirlemiştir. Yabancı dil olarak Türkçe söz varlığını zenginleştirme ile ilgili bilimsel makalelerin eğilimlerini araştıran Maden'in (2020) çalışmasında da örneklemdeki 56 makalenin 54'ünün tek veya çift yazarlı olduğu 
ortaya konulmuştur. Benzer sonuçlar Türkçe eğitimi alanındaki araştırmaları ele alan çalışmalarda (Varışoğlu, Şahin \& Göktaş, 2013; Şeref \& Karagöz, 2019) da ortaya çıkmıştır. Bu sonuçlara göre alanda çalışan akademisyenlerin/araştırmacıların daha çok bireysel çalışmayı tercih ettikleri düşünülebilir. Bununla birlikte yabancı dil olarak Türkçe öğretimi ders kitapları üzerine yapılan çalışmalar doküman incelemesine dayalı ve kişi sayısının az tutulmasına daha uygun olduğundan yazarların böyle bir tercihe yöneldikleri şeklinde bir yorum yapılabilir.

Yabancı dil olarak Türkçe öğretimi ders kitapları üzerine yapılan araştırmaların örneklem tercihine bakıldığında Yeni Hitit Yabancılar İçin Türkçe Öğretim Seti (f=120), İstanbul Yabancılar İçin Türkçe Öğretim Seti (f=108), Yedi İklim Yabancılar İçin Türkçe Öğretim Seti $(\mathrm{f}=105)$ ve Gazi Yabancılar İçin Türkçe Öğretim Seti (f=82) üzerine oldukça fazla çalışma yapıldığı görülmektedir. Burada bahsi geçen kitaplar Güleç ve Ömeroğlu'nun (2016) belirttiği üzere Türkçe Öğretim Merkezlerinde en çok kullanılan kitaplardır. Erdil'in (2018) araştırmasına göre de Yedi İklim Türkçe Öğretim Seti ile İstanbul Türkçe Öğretim Seti üniversitelerde en çok kullanılan dil öğretim kitaplarıdır. Bu durumun araştırmacıların örneklem tercihlerinde etkili olduğu düşünülmektedir. Bununla birlikte "Yeni Hitit" daha çok tezlerde tercih edilirken "İstanbul" daha çok makalelerde tercih edilmiştir. Bu sonuç Ercan'ın (2015) araştırma bulgularıyla benzerlik göstermektedir. İlgili araştırmada yabancılara Türkçe öğretimi tezlerinde en fazla incelenen kitabın "Yeni Hitit" olduğu vurgulanmıştır. Ankara Üniversitesi TÖMER tarafindan hazırlanan ve 2002 yılında "Hitit Yabancılar İçin Türkçe" adıyla yayımlanan bu set 2006 yılından itibaren geliştirilip temel seviye için "Öğretmen Kitabı" da eklenerek "Yeni Hitit" seti oluşturulmuş, Yeni Hitit 1 ve Yeni Hitit 2 ders kitapları 2008 yılından, Yeni Hitit 3 ders kitabı da 2009 yılından itibaren kullanılmaya başlanmıştır (Şimşek, 2011). İstanbul Üniversitesi Dil Merkezince hazırlanan İstanbul Türkçe Öğretim Seti'nin ilk baskısı 2012'de yapılırken (Özbal, 2019) Yunus Emre Enstitüsü tarafından hazırlanan "Yedi İklim" kitap setinin pilot uygulamalarına 2013 yılında başlanmış, yaklaşık 2 yıllık bir süre zarfında eser, geri dönütler çerçevesinde güncellenerek tamamlanmıştır (Başar, 2016). Buna göre Yeni Hitit Türkçe Öğretim Seti'nin tarih olarak daha önce hazırlanmış olmasının, ders kitabı incelemelerinde daha çok kullanılmış olmasını etkilediği tahmin edilmektedir.

Yabancı dil olarak Türkçe öğretimi ders kitapları üzerine yapılan araştırmalarda örneklemdeki kitapların kur düzeyine göre dağılımına bakıldığında en fazla ( $\mathrm{f}=175$, $\% 72,31)$ temel düzey öğrenciler için hazırlanan kitapların örnekleme alındığ 1 ortaya çıkmıştır. Orta düzey öğrenciler için hazırlanan ders kitapları $148(\% 61,15)$, ileri düzey öğrenciler için hazırlanan kitaplar da $113(\% 46,69)$ çalışmada araştırmacılar tarafindan örneklem olarak tercih edilmiştir. Buna göre örneklem tercihlerinde hem makale hem de tezlerde temel düzeyden ileri düzeye doğru kademeli bir düşüşün olduğu görülmektedir. Bunda araştırmacı tercihlerinin ya da kitaplara ulaşma imkânlarının etkili olabileceği düşünülmektedir.

Yabancı dil olarak Türkçe öğretimi ders kitapları üzerine yapılan araştırmaların konu tercihlerine bakıldığında en çok çalışılan başlıkların "söz varlıği/kelime öğretimi” ( $\mathrm{f}=55)$, "kültürel unsurlar/kültür aktarımı" ( $\mathrm{f}=51)$, "temel dil becerilerine yönelik etkinlikler" (f=38) ve "dil bilgisi” (f=37) olduğu görülmektedir. "Söz 
varlığı/kelime öğretimi" tezlerde ( $\mathrm{f}=38)$, "kültürel unsurlar/kültür aktarımı" ise makalelerde $(\mathrm{f}=25)$ en fazla çalışılan konu olmuştur. Biçer'in (2017) araştırmasında sözcük öğretimi $(\% 7,8)$, kültür aktarımı $(\% 6,2)$ ve dil bilgisi öğretimi $(\% 6,29)$ konularının yabancılara Türkçe öğretimi alanında en çok çalışılan konulardan olduğu tespit edilmiştir. Dil bilgisi öğretimi $(\% 16,94)$, sözcük öğretimi $(\% 7,63)$ ve kültür aktarımı $(\% 5,09)$, Ercan'ın (2015) araştırmasında da yabancılara Türkçe öğretimi tezlerinde en çok tercih edilen konulardan olmuştur. Demir ve Özdemir (2017) tarafından gerçekleştirilen çalışmada yabancı dil olarak Türkçe öğretiminde en fazla çalışılan konular arasında dil becerileri $(\% 20,1)$ ile dil bilgisi $(\% 12,8)$ ön plana çıkarken Büyükikiz'in (2014) araştırmasında yabancılara Türkçe öğretimi tezlerinde en çok çalışılan konunun dil bilgisi incelemeleri $(\% 25,85)$ olduğu belirtilmiştir. Benzer şekilde Türkben (2018) de konuyla ilgili tezlerde dil bilgisi öğretiminin ilk sırada $(\% 13,93)$ yer aldığını belirlemiştir. Aynı çalışmada ders kitaplarının en çok dil bilgisi $(\% 31,58)$ ve kültür aktarımı $(\% 22,81)$ açısından incelendiği sonucuna da ulaşılmıştır. Yabancılara Türkçe öğretimi lisansüstü tezlerindeki anahtar kelimeleri belirleyen Küçük ve Kaya'nın (2018) araştırmasında kültür ( $\mathrm{f}=21)$, söz varlığı-kelime sıklığı $(\mathrm{f}=19)$ ve dil bilgisi $(\mathrm{f}=15)$ kavramları tezlerde en sık kullanılan anahtar sözcükler olmuştur. Buna göre yabancı dil olarak Türkçe öğretimi araştırmalarında tercih edilen konuların, ders kitabı incelemelerinde de araştırmacılar tarafindan tercih edilmiş olduğu söylenebilir.

\section{Çıkar Çatışması ve Etik Bildirimi}

"Yabancı Dil Olarak Türkçe Öğretimi Ders Kitapları Üzerine Yapılan Araştırmaların Eğilimleri” başlıklı çalışmanın yazım sürecinde bilimsel kurallara, etik ve alıntı kurallarına uyulmuş, toplanan veriler üzerinde herhangi bir tahrifat yapılmamış ve bu çalışma başka herhangi bir akademik yayın ortamına değerlendirme için gönderilmemiştir. Araştırma doküman incelemesine dayalı olarak gerçekleştirildiğinden etik kurul kararı zorunluluğu bulunmamaktadır.

\section{Kaynakça}

Akın, E. (2016). Yabancılara Türkçe öğretiminde çoklu ortama dayalı öğretimin kullanımı ve bu yönde yapılan bazı çalışmalar üzerine bir inceleme. Akademik Sosyal Araştırmalar Dergisi, 4(24), 151-162.

Arı, G. (2014). Türkçe ders kitaplarında fiziksel ve biçimsel görünüm. H. Ülper (Ed.), Türkçe ders kitabı çözümlemeleri içinde (3. bask1, ss. 39-52). Pegem Yayınları.

Aydın, A. (2010). Kimya I ders kitabının öğretmen görüşlerine göre değerlendirilmesi. Ahi Evran Üniversitesi Kirşehir Ĕ̈itim Fakültesi Dergisi,11(1), 207-224.

Bağcı Ayrancı, B. (2019). Türkiye'de yabancılara Türkçe öğretiminde kültür aktarımı alanında yapılan lisansüstü tezlerin analizi ve değerlendirilmesi. Söylem Filoloji Dergisi, $4(2), 446-454$.

Baki, Y. (2019). Yabancılara Türkçe öğretimi alanındaki araştırma eğilimleri. International Journal of Language Academy, 7(3), 22-41. http://dx.doi.org/10.29228/ijla.25829

Baş, T., \& Akturan, U. (2017). Sosyal bilimlerde bilgisayar destekli nitel araştırma yöntemleri (3. baskı). Seçkin Yayıncılık. 
Batdı, V., \& Oral, B. (2020). Bilimsel araştırmalarda geçerlik ve güvenirlik. B. Oral \& A. Çoban (Eds.), Kuramdan uygulamaya eğitimde bilimsel araştırma yöntemleri içinde (1. bask1, ss. 115-145). Pegem Yayınlar1.

Başar, U. (2016). Yunus Emre Enstitüsü Yedi İklim Türkçe Setinin (Temel seviye: A1, A2) yapılandırmacılık bağlamında değerlendirilmesi. Aydın TÖMER Dil Dergisi, 2(1), 55-77.

Biçer, N. (2017). Yabancılara Türkçe öğretimi alanında yayınlanan makaleler üzerine bir analiz çalışması. Pamukkale Üniversitesi Sosyal Bilimler Enstitüsü Dergisi, 27, 236-247. doi: $10.5505 /$ pausbed.2017.69772

Biçer, N. (2019). Türkçenin yabancı dil olarak öğretilmesinde eğitim ortamları, eğitim ortamlarında kullanılan ders kitapları, materyaller, eğitim teknolojileri. İ. Erdem, B. Doğan \& H. Altunkaya (Eds.), Türkçenin yabancı dil olarak öğretimi içinde (1.baskı, ss. 201-222). Pegem Yayınları.

Biçer, N., \& Alan, Y. (2017). Yabancılara Türkçe öğretiminde kullanılan Yeni Hitit 3 ve İstanbul $\mathrm{C} 1+$ ders kitaplarındaki metinlerin okunabilirlik düzeylerinin karşılaştırılması. Mersin Üniversitesi Eğitim Fakültesi Dergisi, 13(3), 1130-1139. https://doi.org/10.17860/mersinefd.328486

Boyacı, S. \& Demirkol, S. (2018). Türkçe eğitimi alanında yapılan doktora tezlerinin incelenmesi. Ana Dili Eğitimi Dergisi, 6(2), 512-531.

Büyükikiz, K. K. (2014). Yabancılara Türkçe öğretimi alanında hazırlanan lisansüstü tezler üzerine bir inceleme. Mustafa Kemal Üniversitesi Sosyal Bilimler Enstitüsü Dergisi, 11(25), 203-213.

Büyüköztürk, Ş., Kılı̨̧ Çakmak, E., Akgün, Ö. E., Karadeniz, Ş., \& Demirel, F. (2020). Bilimsel araştırma yöntemleri (28. baskı). Pegem Yayınları.

Coşkun, E., \& Taş, S. (2008). Ders kitaplarına metin seçimi açısından Türkçe öğretim programlarının değerlendirilmesi. Mustafa Kemal Üniversitesi Sosyal Bilimler Enstitüsü Dergisi, 5(10), 59-74.

Coşkun, E., Özçakmak, H., \& Balcı, A. (2012). Türkçe eğitiminde eğilimler: 1981-2010 yılları arasında yapılan tezler üzerine bir meta-analiz çalışması. E. Yılmaz, M. Gedizli, E. Özcan \& Y. Koçmar (Eds.), Türkçenin eğitimi-öğretimi üzerine çalışmalar içinde (1. bask1, ss. 204-212). Pegem Yayınları.

Çelebi, C., Ergül, E., Usta, B., \& Mutlu. M. (2019). Türkiye'de yabancılara Türkçe öğretimi alanında hazırlanmış lisansüstü tezler üzerine bir meta-analiz çalışması. Temel Eğitim Dergisi, 1(3), 39-52.

Çiftçi, Ö., \& Coşkun, H. (2017). Yabancılara Türkçe öğretimi alanında yapılan çalışmaların farklı değişkenlere göre tasnifi. International Journal of Language Academy, 5(4), 205214. http://dx.doi.org/10.18033/ijla.3625

Doğan, Y., \& Özçakmak, H. (2014). Dinleme becerisinin eğitimi üzerine yapılan lisansüstü tezlerin değerlendirilmesi. Ana Dili Eğitimi Dergisi, 2(2), 90-99.

Demir, K., \& Özdemir, A. (2017). Yabancı dil olarak Türkçe öğretimi alanındaki bilimsel makalelere bakış. Turkish $\quad$ Studies, $12(14), \quad$ 120. http://dx.doi.org/10.7827/TurkishStudies.11713

Demirel, Ö., \& Kıroğlu, K. (2020). Eğitim ve ders kitapları. Ö. Demirel \& K. Kıroğlu (Eds.), Ders kitabı incelemesi içinde (4. baskı, ss. 4-12). Pegem Yayınları. 
Duman, T., \& Çakmak, M. (2004). Ders kitaplarının nitelikleri. L. Küçükahmet (Ed.), Konu alanı ders kitabı inceleme kılavuzu içinde (2. bask1, ss. 17-32). Nobel Yayınları.

Ekiz, D. (2020). Bilimsel araştırma yöntemleri (6. baskı). Anı Yayıncılık.

Ercan, A. N. (2015). Yabancılara Türkçe öğretimi üzerine yapılmış lisansüstü tezlerin çeşitli değişkenler açısından analizi. M. V. Coşkun vd. (Eds.), Türkçenin ĕgitimi öğretimine yönelik çalışmalar içinde (1. baskı, ss. 2-12). Pegem Yayınları.

Erdil, M. (2018). Türkiye Cumhuriyeti Yükseköğretim Kuruluna bağl1 209 üniversitede yabancılara Türkçe öğretimi. Uluslararası Sosyal Araştırmalar Dergisi, 11(60), 93-112. http://dx.doi.org/10.17719/jisr.2018.2764

Göçer, A. (2008). İlköğretim Türkçe ders kitaplarının ölçme ve değerlendirme açısından incelenmesi. Atatürk Üniversitesi Sosyal Bilimler Enstitüsü Dergisi, 11(1), 197-210.

Güleç, İ., \& Ömeroğlu, E. (2016). Yabancılara Türkçe öğretiminde kullanılan ders kitaplarının biçimsel özellikleri. A. Okur, B. İnce \& İ. Güleç (Eds.), Uluslararası Türkçenin Yabancı Dil Olarak Öğretimi Kongresi tam metin bildiri kitabı içinde (ss. 6983). http://www.tomer.sakarya.edu.tr/upload/yayinlar/3.pdf

Gülen Canl1, M., \& Tepeli, Y. (2019a). Ana dili ve yabancı dil olarak Türkçe eğitimi üzerine eylem araştırması yöntemiyle yapılmış çalışmaların sistematik olarak incelenmesi. International Journal of Field Education, 5(2), 30-54.

Gülen Canlı, M., \& Tepeli, Y. (2019b). Dil bilgisi öğretimi üzerine yapılmış doktora tezlerinin sistematik olarak incelenmesi. International Journal of Social Science Research, 8(2), 60-87.

Gülersoy, A. E. (2013). İdeal ders kitabı arayışında sosyal bilgiler ders kitaplarının bazı özellikler açısından incelenmesi. International Journal of New Trends in Arts, Sports \& Science Education, 2(1), 8-26.

Güzel, D., \& Şimşek, A. (2012). Milli eğitim şûralarında ders kitapları. Sakarya Üniversitesi Eğitim Fakültesi Dergisi, 23, 172-216.

İşeri, K. (2007). Altıncı sınıf Türkçe ders kitabının ilköğretim Türkçe programının amaçlarına uygunluğunun değerlendirilmesi. Dil Dergisi, 136, 58-74.

Karababa, Z. C., \& Üstünsoy Taşkın, S. (2012). Yabancı dil olarak Türkçe öğretiminde kullanılan ders kitaplarının öğretmen görüşleri çerçevesinde değerlendirilmesi. Dil Dergisi, 157, 65-80.

Kurt, B., Direkci, B., \& Caner, M. (2018). Yabancı dil olarak Türkçe öğretimine ilişkin İngilizce öğretmeni adaylarının görüşleri. Turkish Studies, 13(27), 1017-1037. http://dx.doi.org/10.7827/TurkishStudies.14382

Küçük, S., \& Kaya, E. (2018). Yabancı dil olarak Türkçe öğretimi ile ilgili hazırlanan tezlerde geçen anahtar kelimelere yönelik içerik analizi. Journal of History Culture and Art Research, 7(5), 442- 456. http://dx.doi.org/10.7596/taksad.v7i5.1880

Küçükahmet, L. (2004). Eğitim programlarında ders kitabının yeri. L. Küçükahmet (Ed.), Konu alanı ders kitabı inceleme kılavuzu içinde (2.bask1, ss. 1-16). Nobel Yayınları.

Lüle Mert, E. (2013). Türkçe ders ve çalışma kitaplarının sözcüksel görünümlerine ilişkin örnek bir uygulama. Türkiye Sosyal Araştırmalar Dergisi, 172, 151-169.

Maden, A. (2020). Yabancı dil olarak Türkçe söz varlığını zenginleştirme ile ilgili makalelerin analizi. Avrasya Sosyal ve Ekonomi Araştırmaları Dergisi, 7(5), 583-596. 
Mentiş Taş, A. (2007). Yeni sosyal bilgiler ders kitaplarına ilişkin öğretmen görüşlerinin belirlenmesi. Selçuk Üniversitesi Sosyal Bilimler Enstitüsü Dergisi, 17, 519-532.

Miles, M. B., \& Huberman, A. M. (1994). Qualitative data analysis: An expanded sourcebook. (2. bask1). SAGE Publications.

Özbal, B. (2019). Yabancı dil olarak Türkçe ders kitaplarında alıştırmaların incelenmesi: A1A2 düzeyi [Yayımlanmamış doktora tezi]. Hacettepe Üniversitesi.

Özçakmak, H. (2017). Türkçe eğitimi lisansüstü araştırmalarında yeni yönelimler (20112015). Uluslararası Türkçe Edebiyat Kültür Eğitim Dergisi, 6(3), 1607-1618.

Özdemir, C. (2013). Yabancılara Türkçe öğretiminde ders malzemelerinin önemi ve işlevsel ders malzemelerinin nitelikleri. Turkish Studies, 8(1), 2049-2056.

Özkan, R. (2010). Türk eğitim sisteminde himayeci değerler: İlköğretim ders kitapları örneği. Uluslararası Insan Bilimleri Dergisi, 7(1), 1124-1141.

Öztürk, A. T., \& Çerçi, A. (2019). Türkçe öğretmenlerinin ders kitaplarına bağlılıkları ölçeği'nin geliştirilmesi: Geçerlilik ve güvenilirlik çalışması. Ana Dili Eğitimi Dergisi, 7(4), 876-897.

Richards, J. C. (2001). Curriculum development in language teaching (1. bask1). Cambridge University Press.

Serin, N., \& Turan, E. D. (2015). Yunus Emre Türkçe Öğretimi Seti'nde yer alan metinlerin tür, tema ve özgünlük açısından incelenmesi. Uluslararası Türkçe Edebiyat Kültür Eğitim Dergisi, 4(3), 1259-1250.

Sönmez, V., \& Alacapınar, F. G. (2019). Örneklendirilmiş bilimsel araştırma yöntemleri (7. bask1). Anı Yayınc1lı.

Şahin, A. (2008). İlköğretim birinci sınıf Türkçe ders kitabı, öğrenci çalışma kitabı ve öğretmen kılavuz kitabının öğretmen görüşlerine dayalı olarak değerlendirilmesi. Ahi Evran Üniversitesi Kırşehir Eğitim Fakültesi Dergisi, 9(3), 133-146.

Şahin, M. (2012). Ders kitaplarının mesaj tasarımı ilkeleri açısından değerlendirilmesi. Ahi Evran Üniversitesi Kırşehir Eğitim Fakültesi Dergisi, 13(3), 129-154.

Şeref, İ., \& Karagöz, B. (2019). Türkçe eğitimi akademik alanına ilişkin bir değerlendirme: Web of Science veri tabanına dayalı bibliyometrik inceleme. Dil Eğitimi ve Araştırmaları Dergisi, 5(2), 213-231. https://doi.org/10.31464/jlere.578224

Şimşek, P. (2011). Yabancllara Türkçe öğretiminde okuma metinleri ve yardımcı okuma kitapları üzerine bir araştırma [Yayımlanmamış yüksek lisans tezi]. Afyon Kocatepe Üniversitesi.

Tanrikulu, L., \& Akgül, M. N. (2019). İstanbul Yabancılara Türkçe Öğretim Seti temel seviyesinin dil bilgisi bölümlerinin değerlendirilmesi. International Journal of Language and Education Research, 1(1), 26-43. https://doi.org/10.29329/ijler.2019.233.2

Tiryaki, E., \& Doğan, S. Ö. (2017). Yabancılara Türkçe öğretimindeki ders kitaplarındaki okuma metinlerinin bilgi türleri açısından incelenmesi (İstanbul $\mathrm{C} 1 /+$ örneği). Ana Dili Ĕ̈itimi Dergisi, 5(3), 503-518.

Tok, M. (2013). Yabancılara Türkçe öğretimi ders kitaplarındaki yazma çalışmalarının değerlendirilmesi. Uşak Üniversitesi Sosyal Bilimler Dergisi, 6(1), 249-279. 
Tüm, G., \& Ceyhan Bingöl, Z. (2017). Yabancı dil olarak Türkçe öğretiminde kullanılan ders kitaplarının temel işlevleri. Turkish Studies, 12(34), 429-444. http://dx.doi.org/10.7827/TurkishStudies.12654

Türkben, T. (2018). Yabancı dil olarak Türkçe öğretimi alanında yapılan lisansüstü çalışmaların değerlendirilmesi. Uluslararası Türkçe Edebiyat Kültür Eğitim Dergisi, 7(4), 2464-2479.

Ur, P. (1999). A course in language teaching: Practice and theory (1. bask1). Cambridge University Press.

Varışoğlu, B., Şahin, A., \& Göktaş, Y. (2013). Türkçe eğitimi araştırmalarında eğilimler. Kuram ve Uygulamada Eğitim Bilimleri,13(3), 1767-1781.

Yalınkılıç, K. (2014). Bir öğretim aracı olarak ders kitabı. H. Ülper (Ed.), Türkçe ders kitabı çözümlemeleri içinde (3. baskı, ss. 3-19). Pegem Yayınları.

Yıldırım, A., \& Şimşek, H. (2011). Sosyal bilimlerde nitel araştırma yöntemleri (8. baskı). Seçkin Yayıncılık.

Y1lmaz, F., \& Temiz, Ç. (2014). Yabancılara Türkçe öğretiminde kullanılan ders kitaplarındaki metinlerin okunabilirlik durumları. International Journal of Languages' Education and Teaching, 2, 81-91.

\section{Extended Abstract}

Textbooks are one of the first materials that come to mind when it comes to course material. Described as printed teaching material used for learning purposes prepared in accordance with the objectives, content, teaching-learning process and assessment and evaluation dimensions in an educational program (Demirel \& Kıroğlu, 2020) and as learning-teaching material that consists of texts prepared in accordance with the developmental characteristics and level of the student and with the principles of the curriculum and presents the information it contains to the student (Şahin, 2012), textbooks are one of the important tools ensuring that activities of teachers and students in the learning process are carried out in an orderly manner (Göçer, 2008). As in all levels of education, as the carriers of the curriculum (Serin \& Turan, 2015), textbooks are one of the most important materials used in teaching Turkish to foreigners. In the books prepared for the teaching of Turkish as a foreign language, taking the fields of reading, writing, listening and speaking skills and grammar learning into account, it is aimed to develop these skills of foreigners (Biçer \& Alan, 2017). According to Lüle Mert (2013), these books should make use of the language opportunities of Turkish properly and sufficiently, and should have the quality of acquiring and introducing all the features of the language intended for teaching. Although the main purpose of these books is to teach Turkish, they should be prepared in a way that includes the richness of Turkish, Turkish culture and various information (Tiryaki \& Doğan, 2017). The books prepared on teaching Turkish as a foreign language are not only important in language teaching but also an important source of data for researchers working in this field. There are many studies in the literature that attempt to analyze and evaluate these books from various aspects.

This study aiming to determine the trends of the studies on the textbooks of teaching Turkish as a foreign language was carried out through document analysis in 
qualitative research design. Document analysis covers the analysis of written materials that contain information about the phenomenon or facts aimed to be searched (Yıldırım \& Şimşek, 2011). As one of the purposeful sampling methods, criterion sampling was used in the study. The basic understanding in this sampling method is to study all situations that meet a predetermined set of criteria (Y1ldirım \& Şimşek, 2011). The sample of the study consists of articles and theses published between 2010 and 2020. A total of 242 research including 142 theses and 100 articles were included in the study. Theses were accessed through YÖK National Thesis Center, articles on YÖK Academic, Google Scholar and Dergipark databases. These studies were analyzed according to years, educational levels, advisor titles, universities they were prepared for, number of authors, sample selection, course level preference and subjects. The data analyzed through content analysis technique were presented through tables and graphs by finding the frequency (f) and percentage $(\%)$ values.

According to the findings of the study, in the researches on teaching Turkish as a foreign language textbooks, it was observed that postgraduate theses $(59 \%)$ were more than articles (41\%). In the distribution of postgraduate theses by education level, master theses (93\%) are quite higher than doctoral theses $(7 \%)$. In the distribution of the studies by years, it was determined that the highest number of studies was conducted in $2019(\mathrm{f}=73)$ and $2018(\mathrm{f}=42)$. They were followed by 2017 $(\mathrm{f}=25), 2015$ and $2020(\mathrm{f}=24)$. Studies conducted in the last four years between 2017-2020 ( $\mathrm{f}=164)$ correspond to $67.76 \%$ of the studies $(\mathrm{f}=242)$ conducted in an 11-year period (2010-2020). The year with the least number of publications is 2012. Accordingly, it is seen that research on the subject has increased in recent years. It was determined that graduate theses were prepared in 35 different universities, that more than one study were conducted in 22 of these institutions, and that Istanbul University ( $\mathrm{f}=22$ ), Hacettepe University $(\mathrm{f}=14)$, Gazi University $(\mathrm{f}=13)$, Dokuz Eylül University ( $\mathrm{f}=11$ ), Nevşehir Hacı Bektaş Veli University $(\mathrm{f}=10)$, Çanakkale Onsekiz Mart University ( $\mathrm{f}=8$ ) and Tokat Gaziosmanpaşa University ( $\mathrm{f}=7$ ) were the institutions where thesis studies were conducted the most. Considering the titles of the advisors who carry out master's and doctoral theses, it was determined that faculty members with the title of "Prof. Dr." (37\%) and "Assoc. Dr." (36\%) stood out. The rate of the theses conducted by faculty members holding the title of "Dr. Faculty Member / Asst. Prof." is 27\%. It was revealed that "double-author" (46\%) and "single author" (43\%) publications were preferred more for the number of authors. When the samples of the researches are analyzed, it was observed that the most researched textbooks were Yeni Hitit Turkish for Foreigners ( $f=120)$, Istanbul Turkish for Foreigners ( $\mathrm{f}=108)$, Yedi İklim Turkish for Foreigners $(\mathrm{f}=105)$ and Gazi Turkish Teaching Sets $(\mathrm{f}=82)$. When analyzing the course level of the books sampled in the studies, it was found out that in both articles and theses, researchers analyzed the textbooks prepared for basic $(72.31 \%)$ and intermediate level $(61.15 \%)$ students more than the advanced course $(46.69 \%)$ books. It was determined that the topics standing out in the subject preferences of the researches on textbooks are "vocabulary/teaching new words" $(\mathrm{f}=55)$, "cultural elements/transfer of culture" $(\mathrm{f}=51)$, "activities for basic language skills" $(\mathrm{f}=38)$ and "grammar" ( $\mathrm{f}=37)$. 
As a result, it has been observed that the findings of the study are in line with the findings of other studies (Bağc1 Ayranc1, 2019; Baki, 2019; Biçer, 2017; Büyükikiz, 2014; Çelebi, Ergül, Usta \& Mutlu, 2019; Demir \& Özdemir, 2017; Ercan, 2015; Küçük \& Kaya, 2018; Maden, 2020; Türkben, 2018) analyzing the trends of postgraduate theses and articles in the field of teaching Turkish to foreigners. 